\title{
Peningkatan Kemampuan Pengelolaan Homestay Di Desa Wisata Batulayang Kabupaten Bogor Jawa Barat, Indonesia
}

\section{Capacity Building for Homestay Management in Batulayang Tourism Village, Bogor Regency, West Java, Indonesia}

\author{
Dea Prasetyawati ${ }^{1}$, Asep Syaiful Bahri ${ }^{2)}$ \\ ${ }^{1)}$ Program Studi Bisnis Perhotelan Universitas Agung Podomoro, Jakarta, Indonesia \\ ${ }^{2)}$ Program Studi Bisnis Perhotelan Universitas Agung Podomoro, Jakarta, Indonesia
}

19 April 2019

\begin{abstract}
Batulayang Tourism Village is one of the tourist destinations in the Cisarua area of Bogor Peak. This area actually has good tourism development potential with various tourist objects and attractions including natural potential (landscapes, waterfalls, village, natural atmosphere, rivers), cultural potential (traditional dance, village specialties), artificial tourism (outbound, camping ground, paragliding, hiking, tracking, and tree top). The current condition of Batulayang Tourism Village has been visited by many tourists, however, it still has not been positive for the surrounding community. The surrounding community is more of a spectator and watched by tourists. Even if the community is involved in the management of the tourist area, it will have a positive impact on increasing community income. Community service regarding the improvement of homestay management capabilities in Batulayang Tourism Village, Bogor Regency was attended by 20 homeowners whose homes were willing to be used as homestays. The service method that is carried out is by conducting lectures (counseling), discussions and presentations. The results of this community service are that the provision of knowledge and technology on improving homestay management capabilities in Batulayang Tourism Village, Bogor Regency is well received by the homestay owner and reaches the planned destination. This is indicated by the ability of homestay owners to be able to interact with tourists and provide opportunities for tourists to provide input and advice to homestay owners. In addition, almost the entire implementation of this service has been carried out according to the planning schedule, method, and reseach results; written in 1 paragraph, single space among rows, using past tense
\end{abstract}

Keywords: Homestay Management, Batulayang Tourism Village, Bogor, West Java, Indonesia

\begin{abstract}
ABSTRAK
Desa Wisata Batulayang merupakan salah satau daerah tujuan wisata yang berada di daerah Cisarua Puncak Bogor. Kawasan ini sesungguhnya memiliki potensi pengembangan wisata yang baik dengan adanya berbagai obyek dan atraksi wisata diantaranya adalah potensi alam (bentang alam, air terjun, suasana alam desa, sungai), potensi budaya (tari tradisonal, kuliner khas desa), wisata buatan (outbond, camping ground, paralayang, hiking, tracking, dan tree top). Kondisi saat ini Desa Wisata Batulayang telah banyak dikunjungi oleh wisatawan, namun demikian masih belum bermpak positif bagi masyarakat sekitar. Masyarakat sekitar lebih banyak menjadi penonton dan di tonton oleh para wisatawan. Padahal jika masyarakat tersebut dilibatkan dalam pengelolaan kawasan wisata maka akan memberikan dampak prositif bagi peningkatan pendapatan masyarakat. Pengabdian kepada masyarakat mengenai peningkatan kemampuan pengelolaan homestay di Desa Wisata Batulayang Kabupaten Bogor diikuti oleh 20 pemilik rumah yang rumahnya bersedia dijadikan sebagai homestay. Metode pengabdian yang dilakukan yakni dengan melakukan ceramah (penyuluhan), diskusi dan presentasi. Adapun hasil dari pengabdian kepada masyarakat ini adalah bahwa pemberian ilmu pengetahuan dan teknologi mengenai peningkatan kemampuan pengelolaan homestay di Desa Wisata Batulayang Kabupaten Bogor diterima dengan baik oleh pihak pemilik homestay dan mencapai tujuan yang sudah direncanakan sebelumnya. Hal ini ditandai dengan kemampuan para pemilik homestay untuk dapat berinteraksi dengan wisatawan serta memberikan kesempatan untuk para wisatawan dalam memberikan masukan serta saran kepada pemilik homestay. Selain itu, Hampir keseluruhan pelaksanaan pengabdian ini sudah terlaksana sesuai jadwal perencanaan
\end{abstract}

Kata kunci: Pengelolaan Homestay, Desa Wisata Batulayang, Bogor, Jawa Barat, Indonesia. 


\section{PENDAHULUAN}

Pariwisata merupakan berbagai macam kegiatan wisata yang didukung berbagai fasilitas serta layanan yang disediakan masyarakat, pengusaha, Pemerintah dan Pemerintah Daerah (Undang-undang No. 10 Tahun 20019 Tentang Kepariwisataan). Berdasarkan hal tersebut dapat dikatakan bahwa setiap wisatawan yang ingin melakukan perjalanan wisata kesuatu daerah tujuan wisata dengan tujuan rekreasi, pengembangan pribadi, mempelajari keuninkan daya tarik wisata sudah dipastikan akan membutuhkan faslitas, layanan serta informasi. Salah satu fasilitas yang dibutuhkan bagi wisatawan adalah tempat menginap didaerah tujuan wisata tersebut. Kebutuhan akan tempat menginap inipun menjadi salah satu hal menarik untuk dikaji hal ini disebabkan karena banyak wisatawan yang ingin mencoba menginap dan sekaligus berbaur dan bersosialisasi dengan warga sekitar. Atraksi wisata yang sesuai dengan keinginan wisatawan ini adalah dengan menjadikan rumah-rumah penduduk di sekitar daerah tujuan wisata dijadikan sebagai tempat menginap atau yang sering disebut dengan homestay. Jadi dengan demikian homestay merupakan bagian dari daya tarik wisata yang didapatkan oleh wisatawan dalam kungjungannya ke daerah tujuan wisata atau desa wisata (Kemenpar, 2016). Secara prinsip, merupakan rumah tinggal pendudukan di desa wisata yang sebagian kamarnya disewakan kepada wisatawan serta adanya interaksi antara wisatawan dengan pemilik rumah (Kemenpar 2016).

Kegiatan wisata yang berbasis sosioculturaleducation akan mebuka peluang dari masyarakat local kepada para wisatawan sebagai media pembelajaran social (social learning) dengan melakukan sikap interaksi langsung, bersosialisasi, berkomunikai serta menjaling hubungan yang harmonis atas dasar saling menghormati, meghargai taradisi budaya lain (kearifan local). Hal ini bisa dilaksanakan dengan mengembangkan homestay yang awalnya hanya sebagai tempat menginap wisatawan namun dikembangkan menjadi salah satu atraksi wisata.

Desa Wisata Batulayang merupakan salah satau daerah tujuan wisata yang berada di daerah Cisarua Puncak Bogor. Kawasan ini sesungguhnya memiliki potensi pengembangan wisata yang baik dengan adanya berbagai obyek dan atraksi wisata diantaranya adalah potensi alam (bentang alam, air terjun, suasana alam desa, sungai), potensi budaya (tari tradisonal, kuliner khas desa), wisata buatan (outbond, camping ground, paralayang, hiking, tracking, dan tree top). Kondisi saat ini Desa Wisata Batulayang telah banyak dikunjungi oleh wisatawan, namun demikian masih belum bermpak positif bagi masyarakat sekitar. Masyarakat sekitar lebih banyak menjadi penonton dan di tonton oleh para wisatawan. Padahal jika masyarakat tersebut dilibatkan dalam pengelolaan kawasan wisata maka akan memberikan dampak prositif bagi peningkatan pendapatan masyarakat.

Salah satu cara untuk dapat meningkatkan pendapatan masyarakat di Desa Wisata Batulayang adalah mengembangkan rumah penduduk sebagai homestay atau tempat menginap para wisatawan. Sehingga wisatawan tidak menginap di villa, holtel atau pondok wisata disekitas Desa Wisata Batulayang. Namun demikian saat ini masih dari rumah penduduk di Desa Wisata Batulayang yang bersedia dijadikan homestay dan jika sudah ada homestay namun homsetay tersebut belum terstandarisasi dan pengelolanyapun belum memahami secara benar maksud serta tujuan dari diadakannya homestay di Desa Wisata Batulayang tersebut.

\section{LANDASAN TEORI \\ Desa Wisata}

Desa wisata merupakaan suatu bentuk integrasi antara atraksi, akomodasi dan fasilitas pendukung yang disajikan dalam suatu struktur kehidupan masyarakat yang menyatu dengan tata cara dan tradisi yang berlaku. (Nuryanti, Wiendu. 1993). Sedangkan Menurut Priasukmana \& Mulyadin (2001), Desa Wisata merupakan suatu kawasan pedesaan yang menawarkan keseluruhan suasana yang mencerminkan keaslian pedesaaan baik dari kehidupan sosial ekonomi, sosial budaya, adat istiadat, keseharian, memiliki arsitektur bangunan dan struktur tata ruang desa yang khas, atau kegiatan perekonomian yang unik dan menarik serta mempunyai potensi untuk dikembangkanya berbagai komponen kepariwisataan, misalnya atraksi, akomodasi, makanan-minuman, cinderamata, dan kebutuhan wisata lainnya. 
Selain itu, Desa wisata biasanya berupa kawasan pedesaan yang memiliki beberapa karakteristik khusus yang layak untuk menjadi daerah tujuan wisata. Dikawasan ini, penduduknya masih memiliki tradisi dan budaya yang relative masih asli. Selain itu, beberapa faktor pendukung seperti makanan khas, sistem pertanian dan sistem sosial turut mewarnai sebuah kawasan desa wisata. Di luar faktor-faktor tersebut, sumberdaya alam dan lingkungan alam yang masih terjaga merupakan salah satu faktor penting dari sebuah kawasan desa wisata. Selain berbagai keunikan tersebut, kawasan desa wisata juga dipersyaratkan memiliki berbagai fasilitas untuk menunjangnya sebagai kawasan tujuan wisata. Berbagai fasilitas ini akan memudahkan para pengunjung desa wisata dalam melakukan kegiatan wisata. Fasilitas-fasilitas yang seyogyanya ada disuatu kawasan desa wisata antara lain : sarana transportasi, telekomunikasi, kesehatan, dan akomodasi. Khusus untuk sarana akomodasi, desa wisata dapat menyediakan sarana penginapan berupa pondok-pondok wisata (Home Stay) sehingga para pengunjung dapat merasakan suasana pedesaan yang masih asli.

\section{Atraksi Wisata}

Menurut Swarbrooke (2008) Atraksi adalah komponen terpenting dalam sistem pariwisata yang merupakan motivasi utama wisatawan melakukan suatu perjalanan. Faktor yang paling menentukan dari sebuah atraksi adalah satu unit, suatu tempat yang sangat kecil dan dibatasi oleh daerah geografis berdasarkan sebuah fitur utama. Sedangkan destinasi merupakan daerah yang lebih besar yang didalamnya terdapat beberapa atraksi dan fasilitas pendukung lainnya yang dibutuhkan oleh wisatawan. Atraksi tersebut dibagi menjadi dua, yaitu atraksi primer dan atraksi sekunder.

Didalam atraksi wisata akan dipastikan dan sesesuaikan dengan daya tarik wisata yang dimiliki, hal ini disebabkan karena daya tarik merupakan segala sesuatu yang memiliki keunikan, keindahan, dana nilai yang berupa keanekaragaman kekayaan alam budaya dan hasil buatan manusia yang menjadi sasaran atau tujuan kunjungan wisatawan (Undang-undang Nomor 10 Tahun 2009 tentang Kepariwisataan).

Berdasarakan hal tersebut maka dapat disepakati bahwa daya tarik wisata terdiri dari daya tarik wisata budaya, daya tarik wisata alam dan daya tarik wisata buatan yang nantinya akan dikemas sehingga menjadi atraksi wisata di destinasi wisata.

\section{Homestay}

Homestay, secara prinsip, merupakan rumah tinggal penduduk di desa wisata yang sebagian kamarnya disewakan kepada wisatawan serta adanya interaksi antara wisatawan dengan pemilik rumah (Kemenpar 2016). Adapun fungsi homestay antara lain; 1) homestay sebagai sarana akomodasi di desa wisata, 2) homestay sebagai bagian atraksi (daya tarik) dari desa wisata, 3) sebagai sarana interaksi antara wisatawan dengan tuan rumah, 4) sebagai sarana edukasi bagi wisatawan untuk belajar kearifan lokal, 5) sebagai sarana pengenalan budaya. Konsep homestay memadukan antara penginapan dengan biaya terjangkau dan pengalaman budaya lokal yang otentik. Pengembangan homestay akan dilakukan dengan menggerakkan komunitas lokal di desa, sebagai bagian dari pengembangan Desa Wisata.

Berdasarkan hal tersebut maka dapat dikatakan pada homestay, selain dijadikan sebagai saran menginap wisatawan, namun dapat juga dijadikan sebagai atraksi wisata yang dengan membuat produk wisata yang berbasiskan kepada homestay.

\section{METODE PENELITIAN}

Pengabdian kepada masyarakat mengenai peningkatan kemampuan pengelolaan homestay di Desa Wisata Batulayang Kabupaten Bogor diikuti oleh 20 pemilik rumah yang rumahnya bersedia dijadikan sebagai homestay. Terdapat beberapa metode pengabdian yang dilakukan yakni dengan melakukan ceramah (penyuluhan) yang menekankan kepada sadar wisata dan bagaimana mengembangkan homestay dengan menciptakan atraksi wisata yang berbasi kepada homestay. Setelah melakukan caramah (penyuluhan), para pemiliki homestay akan berdiskusi secara kelompok untuk menyusun atraksi wisata yang nantinya akan diterapakan di homestay masingmasing. Setelah berdiskusi mereka akan mempresentasikan hasil diskusinya dan akan dikomentari oleh pemiliknya homestay yang lainnya, sehingga nantinya akan mendapatkan aktraksi wisata yang telah disepakati oleh para pemilik homestay dan akan dijadikan sebagai atraksi wisata di homestay.

\section{HASIL DAN PEMBAHASAN}

Sebagai mitra pengabdian kepada masyarakat, homestay di Desa Wisata Batulayang sangat antusian sekali mengikuti kegiatan ini, hal ini terlihat dari animo pemilik homestay yang mengikuti dan berpartisipasi aktif dalam kegiatan ini. Pemiliki homestay menyadari bahwa kegiatan ini akan memberikan dampak yang positif bagi 
peningkatan kapasitas serta pendapatan para pemiliki homestay.

Proses pelaksanaan pengabdian dilaksanakan dengan penjadwalan selama satu bulan untuk kegiatan Peningkatan Kemampuan Pengelolaan Homestay di Desa Wisata Batulayang Kabupaten Bogor Jawa Barat Indonesia. Adapun pelaksanaan pelatihan dimulai dari tanggal 29 Oktober sampai dengan 16 November 2018. Kegiatan pengabdian masyarakat dapat diterima dengan baik dan berjalan lancar. Para pemilik homestay lebih termotivasi untuk melakukan praktek peningkatan pengelolaan homestay. Berdasarkan hasil monitoring dan evaluasi ternyata para pemiliki homestay telah membuat buku tamu di mana buku tamu tersebut berisikan mengenai nama wisatawan, asal wisatawan serta tujuan wisatawan. Namun untuk menambah kemampuan dalam mengelola homestay, di buku tersebut juga tersedia kolom mengenai pendapat atau saran dari tamu mengenai pelayanan yang diberikan.

Hal ini sangat baik sekali dalam rangka memberikan motivasi kepada pemilik homestay dalam memperbaiki dan mengembangkan pelayanan serta atraksi wisata yang ada di homestay Desa Wisata Batulayang. Untuk saat ini, para pemilik homestay telah membentuk paguyuban pemilik homestay atau sering disebut dengan kelompok homestay. Tentu saja kelompok pemilik homestay Desa Wisata Batulayang masih berada di bawah koordinasi KOMPEPAR (kelompok penggerak pariwisata) Desa Wisata Batulayang.

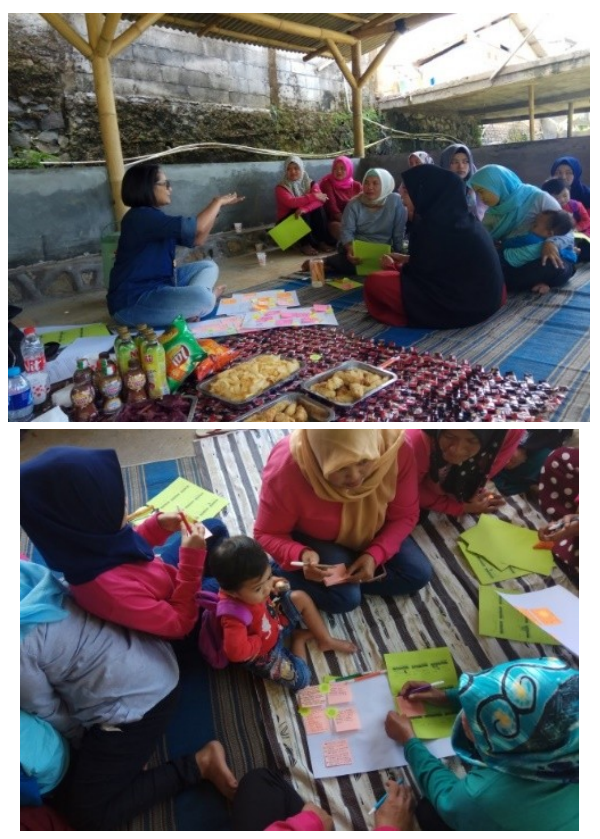

Gambar 1. Sedang Memberikan Penyuluhan Mengenai Kemampuan Pengelolaan Homestay Dan Para Ibu Pemilik Homestay Berdiskusi Mengenai Pengelolaan Homestay

Peningkatan kemampuan para pemiliki homestay dalam melakukan pengelolaan homestay boleh dikatakan telah menemui sasaran. Dalam hal ini para pemilik homestay telah memahami pentingnya pengelolaan homestay dari mulai menerima wisatawan, melayani wisatawan sampai kepada mengajak wisatawan untuk dapat terlibat langsung aktivitas pemilik homestay.

Dalam perjalanannya peningkatan kemampuan dalam mengelola homestay perlu diimbangi dengan kemampuan pemilik homestay dalam melakukan interaksi dengan wisatawan terutama wisatawan yang berasarl dari luar negeri, hal ini dikarenakan masih banyak pemilik homestay yang belum mampu berbahasa inggris sehingga jika ada wisatawan luar negeri yang datang mereka para pemiliki homestay masih bingung untuk melakukan komunikasi dengan para wisatawan tersebut.

\section{SIMPULAN}

Berdasarkan hasil kegiatan Pengabdian masyarakat ini, maka dapat ditarik kesimpulan sebagai berikut: pemberian ilmu pengetahuan dan teknologi mengenai peningkatan kemampuan pengelolaan homestay di Desa Wisata Batulayang Kabupaten Bogor diterima dengan baik oleh pihak pemilik homestay dan mencapai tujuan yang sudah direncanakan sebelumnya. Hal ini ditandai dengan kemampuan para pemilik homestay untuk dapat berinteraksi dengan wisatawan serta memberikan kesempatan untuk para wisatawan dalam memberikan masukan serta saran kepada pemilik homestay. Selain itu, Hampir keseluruhan pelaksanaan pengabdian ini sudah terlaksana sesuai jadwal perencanaan.

\section{SARAN}

Adapun saran dalam pengabdian yang datang adalah dengan memberikan pelatihan kepada para pemikilik homestay berupa kegiatan pelatihan bahasa Inggris untuk pariwisata yang menitikberatkan kepada conversation yang dilakukan oleh para pemilik homestay ketika bertemu tamu dari luar negeri.

\section{DAFTAR PUSTAKA}

Bahri, A. S 2018. Pengembangan Kapasitas Ekonomi Berbasis Masyarakat Di 
Desa Wisata Cibuntu. Indonesia Journal of Cultural and Community Development. Vol 1, No 2 (2018). Universitas Muhammdiyah Sidoarjo. Jawa Timur.

Bhuniya, Md. Anowat Hossain et, al. (2012). "Homestay Accomodation for Tourism Development in East Coast Economic Region" (2012). American Journal of Applied Science 9" 1085 1090

Djogo, T., Sunaryo, S. D., \& Sirait, M. (2003). Kelembagaan dan kebijakan dalam pengembangan agroforestri Bahan ajaran agroforestri 8. Bogor: World Agroforestry Centre (ICRAF) Southest Asia.

Humanika Ibrahim, Yahaya dan Abdul Rasid Abdul Razzaq. (2010). "Homestay Program and Rural Community" Jurnal Homestay Vol 02

Kemenpar, 2016. Panduan Pengelolaan Homestay di Desatinasi Pariwisata. Kementrian Pariwisata Republik Indonesia Deputi Bidang Pengembangan Destinasi dan Industri Pariwisata Asisten Deputi Tata Kelola Destinasi dan Pemberdayaan Masyarakat.

Milen, A. (2006). Capacity Building: Meningkatkan Kinerja Sektor Publik. Yogyakarta: Pembaruan. Damanik, J., \& Weber, H. F. (2006). Perencanaan ekowisata: Dari teori ke aplikasi. Yogyakarta: Puspas UGM dan Andi.

Moleong, Lexy J. (2013). Metode Penelitian Kualitatif. Edisi Revisi. Bandung : PT. Remaja Rosdakarya

Nuryanti, Wiendu (1993). Concept, Perspective and Challenges, makalah bagian dari Laporan Konferensi Internasional mengenai Pariwisata Budaya.: Gadjah Mada University Press, Yogyakarta

Oka A. Yoeti. (2011). Pengantar Ilmu Pariwisata, Jakarta : Pradnya Paramita

Priasukmana, Soetarso dan R. Mohamad Mulyadin. (2001). Pembangunan Desa Wisata : Pelaksanaan Undang-undang Otonomi Daerah. Info Sosial Ekonomi.

Swarbrooke, J., Horner, S. (2007). Consumer Behaviour In Tourism. Burlington

Undang-undang Republik Indonesia No. 10 Tahun 20019 Tentang Kepariwisataan 